\title{
Factors Influencing the Residential Land Use Right Mortgage in Yen My District, Hung Yen Province, Vietnam
}

Pham Phuong Nam, Vietnam National University of Agriculture, Vietnam

\begin{abstract}
The study aims to identify influencing factors and their influences on the residential land use right mortgage as the basis for proposing solutions to improve land use right mortgage. The study used methods of collecting secondary and primary data and processing and analyzing data using SPSS20.0 software. There were 5,268 cases of land use right mortgage registration, 3,240 cases of land use right mortgage removal, and 924 cases for changing contents of land registration. The study identified seven factor groups with 27 factors affecting land use right mortgage. The credit factor group has the biggest impact at the rate of $18.21 \%$, followed by the six other factor groups. Solutions which need to be implemented include completing procedures for reviewing mortgage loan documents; amending and adding regulations on mortgage lending; completing procedures to handle mortgage debt; completing human resources, facilities, and mortgage registration procedures; freeing loan dossier evaluation.
\end{abstract}

\section{KEYWORDS}

Credit, Influencing Factors, Mortgage, Residential Land Use Rights, Yen My

\section{INTRODUCTION}

The mortgage is one of the widely used financial instruments in pre-modern Europe in which land is the most used asset as a security for debt payment because it cannot be disappeared or moved elsewhere (Briggs \& Zuijderduijn, 2018). The mortgage of land is also one of the measures to limit risks and to ensure the performance of obligations in civil, economic and commercial transactions and is the basis for generating the validity of the mortgage contract. In Vietnam land mortgage is understood as mortgage of land use rights because land is owned by the entire people and is uniformly managed by the state. So far there have been many studies on various aspects of land mortgage. Fisher's research focused on the disadvantages and risks faced by lenders (Fisher, 2006). Research by Bogin \& Shui aimed to build a model of rural land pricing to meet different needs, including determining land prices when taking out a mortgage (Bogin \& Shui, 2020). Research by Blackburn \& Vermilyea aimed at determining home prices that are beneficial to mortgage borrowers (Blackburn \& Vermilyea, 2007). Cho and Megbolugbe's research focused on the ethical issue of valuing mortgages when borrowers used them as collateral (Cho \& Megbolugbe, 1996).

The research of Zhimin \& Jianchao focused on pointing out the limitations in the agricultural land mortgage lending policy and proposing to complete the policy in accordance with local practical conditions (Zhimin \& Jianchao, 2017). Burns' mortgage reviews have shown that restrictions on 
mortgage loans cause borrowers to pay higher interest rates than normal and suffer property losses when they are not eligible to repay (Burns, 2017). Li's study proposed an asset mortgage model to limit the possible shortcomings associated with mortgage loans (K. Li, 2017). Zhimin \& Jianchao pointed out the impact of agricultural land mortgage rights on farm production decisions (Zhimin \& Jianchao, 2017). Lee \& Bostic pointed out the reasons for organizing mortgage lending decisions faster in low - middle income areas (Lee \& Bostic, 2020). The other studies pointed out the factor that had impact on mortgage contracts was dealing with insolvable debts (Aikhuele \& Turan, 2018; Bello, 2017).

A number of other studies focused on assessing the risks of mortgage lending and Jintao proposed some solutions to limit the possible risks (Anjum et al., 2019; Chauvet et al., 2016; Salampessy et al., 2019). According to the other authors to facilitate the mortgage and effectively use the land potential, the policy element has a particularly important role. As such, the policy affects land mortgage and it is the foundation for resolving possible disputes (Ertl et al., 2020; Galli, 2020; Wang et al., 2020). On the contrary, Resmawan \& Andjarwati's research showed that the factor influencing land mortgage is mortgage registration so it is necessary to modernize the mortgage registration system (Resmawan \& Andjarwati, 2018). Besides, the too simplified procedure of mortgage lending by land created risks for the borrower when they become insolvent (Anderson \& Kurzer, 2020; Mizuno \& Odake, 2019). Wardhana \& Witasari's research results also shown that mortgage lending procedures affected land mortgage (Wardhana \& Witasari, 2018). According to Steil et al.'s study, ethnicity also affected land mortgage (Steil et al., 2018). Do \& Iyer (2008) pointed out that the legal basis is a fundamental factor for realizing land mortgage as stipulated in Vietnam's 1993 Land Law (Do \& Iyer, 2008). In contrast, in Poland, the database of land and properties attached to land affected the land mortgage (Anna, 2020). Susilowati \& Gunarto's research was aimed at unlicensed land mortgages and legal consequences that might occur when one of the parties to the mortgage contract did not exist (Basharat, 2020; Susilowati $\&$ Gunarto, 2018). According to the other researches, loan interest rates affected mortgage lending. When interest rates rose, the number of mortgage loans decreased and vice versa (Anenberg et al., 2019; Gallin et al., 2021). In addition, real estate laws affect the rights of property owners, including land mortgage rights (Levine-Schnur, 2020). The other studies focused on studying the changes in interest rates affecting the decision to mortgage land and pointed out that, when interest rates fall, demand for real estate increases sharply (Akhter et al., 2021; Martin \& Hanson, 2016).

Shi's research showed that the factor handling mortgage when the borrower is insolvent affects the mortgage loan by land (Shi, 2016). Mączyńska \& Kwartnik-Pruc pointed out the role of mortgage registration and the limitations of the law in land mortgage registration and the proposal to complete the mortgage registration policy (Mączyńska \& Kwartnik-Pruc, 2017). Hanewald et al. researched on housing and land reverse mortgages of the elderly and the possible legal consequences (Hanewald et al., 2020). Li \& Yavas also assessed the main risks when lending houses and land, including the important factor Loan-to-Value Ratio (Li \& Yavas, 2017). The studies in the book edited by Briggs $\&$ Zuijderduijn focus on the process of mortgage formation and development in loan operations and show the important role of land as an effective mortgage (Briggs \& Zuijderduijn, 2018). Mulolwa stated the rules for mortgage registration when using land as collateral and the role of cadastral records when taking land mortgage loans (Mulolwa, 2016). Ye \& Gao studied in depth the financial risks of agricultural land mortgages and set up a financial risk assessment system for agricultural land mortgages (Ye \& Gao, 2019). Research by Sulasningsih et al. focused on the role of mortgage registration for lenders and third parties in land transactions (Sulasningsih et al., 2020). Ambrose et al. also showed that different mortgage interest rates apply to different borrowers, who know the laws and mortgage markets are often allowed to borrow at lower interest rates (Ambrose et al., 2020). Yang et al. pointed out the heterogeneous impact of the rural land mortgage lending program on the borrower's income (Yang et al., 2018). In particular, according to Zhang's research, factors affecting housing mortgages include characteristics of residents, economic status, perception of mortgages and traditional society (Zhang, 2020). 
Bello'research focused on limitations and shortcomings in the law on land mortgage and enforcement of the law on land mortgage (Bello, 2017). Specifically, the research has shown that the provisions of the law on mortgage are not strict, applying the law in resolving disputes in courts between the parties in dealing with the remaining mortgage rights due to the complicated procedures and delay. The other research pointed out that the agreement on loan interest rates and the amount borrowed based on the value of land was a major impact on land mortgage when borrowing money, was also the issue that needs to be negotiated the most between the lender and the borrower (Hendershott $\&$ Pryce, 2006). Tzioumis'research focused on assessing the shortcomings and limitations in land registration as the mortgage registration fee is still high and the professional capacity of officers conducting land registration and legal knowledge of Mortgages are still limited (Tzioumis, 2017). The other research by Stefan \& Rusu (2017); Park (2016) focused on the impact of interest rates and lending procedures as well as the disbursement time on mortgages.

The above studies only focused on evaluating one or a number of factors affecting land mortgage such as legal factors or interest rates, or cadastral records or mortgage handling factor without giving a method to determine all of the affecting factors and their impact level on the land mortgage. Therefore, this article presents the method of determining all the influencing factors and their impact level on the land mortgage.

In order to test the method to assess the factors affecting land use right mortgage, the study selected Yen My district, Hung Yen province as a research site because in the last 5 years there have been many land use right mortgage cases and subject to the impact of many different factors. Besides, up to now, there have not been studies on this issue.

\section{MATERIAL AND METHODS}

\section{Research Scope}

Research on factors valued affecting the mortgage of residential land use rights of households by secondary data in the 2015-2019 period in Yen My district, Hung Yen province. Primary data were collected in July, 2020.

\section{Methods of Collecting Secondary Data}

Data on natural, economic and social conditions are collected at Yen My Statistical Office. Data on land management, including mortgage of land use rights are collected at Yen My Office of Natural Resources and Environment, Branch of Yen My Land Registration Office. The results of research on land mortgage are collected from scientific publications.

\section{Methods of Collecting Primary Data}

Survey data on factors affecting mortgage of land use rights is collected by using printed forms in 2020 through 2 steps. Step 1 randomly investigates people who have mortgaged land use rights in the 2015-2019 period to determine the factors affecting the mortgage. The content of the questionnaire includes information about the respondents and the hypothetical factors affecting the mortgage of land use rights. Respondents can also add other influencing factors to the lower part of the questionnaire. The hypothetical factors affecting the mortgage of land use rights are inherited from previous studies and according to the survey results of the author before making an official questionnaire. The influencing factors selected to assess its level of influence in step 2 are the ones rated by over 50\% total of respondents. The number of respondents is determined by the formula 1 .

$\mathrm{n}=\mathrm{t}^{2} \cdot \mathrm{p} \cdot \mathrm{q} / \mathrm{e}^{2}$ 
Where: $\mathrm{n}$ - the number of people investigating; $\mathrm{t}$ - distribution value corresponding to the selected confidence level; $\mathrm{p}$ - estimated percentage of the population; $\mathrm{q}=1$ - $\mathrm{p}$; e - permissible error $(5 \div$ $15 \%$ ). The study selected the confidence level of $95 \%$, the corresponding distribution value is 1.96 , permissible error $10 \%$ and estimated percentage of the population 0.5 so $q=1-0.5=0.5$. Substituting numbers for formula 1 we have $\mathrm{n}=96$. The study investigated 100 people. The survey results showed that there were 27 influencing factors and are classified into 7 groups of factors affecting mortgage by land (Credit factor group, Mortgage registration factor group, Legal factor group, Human factor group, Facilities Factor group, Financial obligation factor group, Dealing factor group) (Table 1).

Table 1. Groups of factors influencing land use right mortgage in Yen My district

\begin{tabular}{|c|c|}
\hline The group of factors & The group of factors \\
\hline 1. Credit factor group $(C F)$ & - Professional qualification (HF1) \\
\hline - Determining the value of mortgaged land (CF1) & - Communication skills (HF2) \\
\hline - Loan amount (CF2) & - Ability to coordinate to solve tasks (HF3) \\
\hline - Loan term (CF3) & - Ability to solve situations (HF4) \\
\hline - Loan interest rate (CF4) & 5. Facilities factor group $(F F)$ \\
\hline - Document evaluation and disbursement time (CF5) & - Cadastral database (FF1) \\
\hline 2. Mortgage registration factor group $(R F)$ & - Cadastral data storage device (FF2) \\
\hline - Guidance on preparing mortgage registration file (RF1) & - Place of receiving and processing dossiers (FF3) \\
\hline - Profile content (RF2) & 6. Financial obligation factor group $(\mathrm{OF})$ \\
\hline - Processing time (RF3) & - Loan evaluation fee (OF1) \\
\hline - Application method (RF4) & - Notarization fee of mortgage contract (OF2) \\
\hline 3. Legal factor group $(L F)$ & - Mortgage registration fee (OF3) \\
\hline - Land Mortgage Regulations (LF1) & 7. Dealing factor group $(D F)$ \\
\hline $\begin{array}{l}\text { - Dissemination of regulations on land use right mortgage } \\
\text { (LF2) }\end{array}$ & - Form of dealing with mortgage lands (DF1) \\
\hline - Knowledge of mortgage tenors' regulations (LF3) & - Civil procedure (DF2) \\
\hline $\begin{array}{l}\text { - Sense of compliance with the mortgage policy of } \\
\text { borrowers (LF4) }\end{array}$ & - Land auction (DF3) \\
\hline 4. Human factor group $(\mathrm{HF})$ & - Judgment execution (DF4) \\
\hline
\end{tabular}

Step 2 investigates the influence of factors on mortgages through a 5-level Likert scale (Likert, 1932) using printed sheets. The content of the questionnaire includes the personal information of the respondents, the influencing factors, the level of influence of each factor by 5 levels and opinions of the respondents about the advantages and disadvantages and reasons for mortgaging with land use rights as a basis for evaluating and proposing solutions. Evaluation score: very influential - 5 points; quite influential - 4 points; little influential - 3 points; quite little influential - 2 points; very little influential - 1 point. The classification of average influence of factors on mortgage is shown in Table 2.

In order to assess the influence of groups of factors affecting land use right mortgage, the study conducted random surveys of people who had registered for mortgage using land in the research period using printed paper form. The number of survey samples was determined based on the requirements of Exploratory Factor Analysis (EFA) and multivariate regression with at least 5 observations for 1 measurement variable (Hoang and Nguyen, 2008). Therefore, with 27 measurement variables 


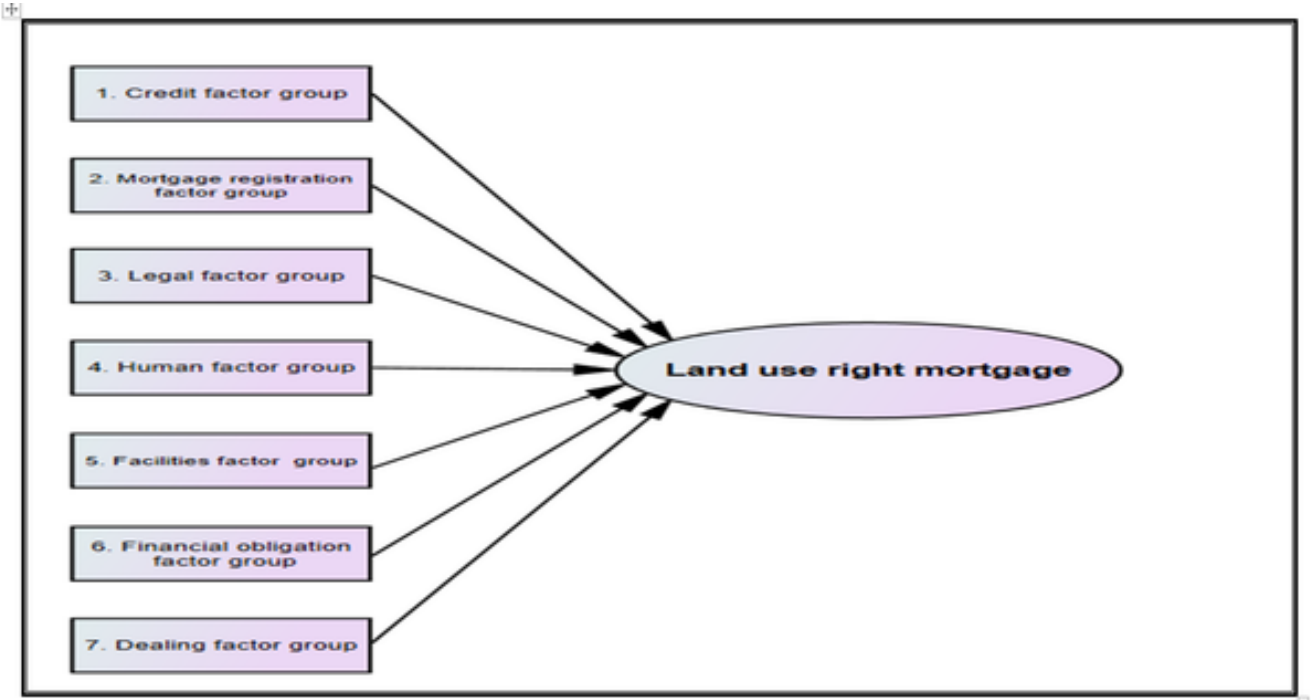

Table 2. Hierarchy of influence

\begin{tabular}{|l|l|l|}
\hline \multicolumn{1}{|c|}{ Scale } & \multicolumn{1}{c|}{ Score } & \multicolumn{1}{c|}{ Rating index } \\
\hline Very influential & 5 & $>=4.20$ \\
\hline Quite influential & 4 & from 3.40 to 4.19 \\
\hline Little influential & 3 & from 2.60 to 3.39 \\
\hline Quite little influential & 2 & from 1.80 to $<2.59$ \\
\hline Very little influential & 1 & $<1.80$ \\
\hline
\end{tabular}

belonging to 07 groups of influencing factors, the number of samples is 135 . For multivariate regression analysis, the minimum sample size to achieve is $50+8 * \mathrm{p}$ ( $\mathrm{p}$ is the number of variables $\mathrm{p}=7$ ) (Tabachnick and Fidell, 1996), so the minimum number of survey samples is 106. In order to ensure both the requirements of exploratory factor analysis and multivariate regression analysis, the study investigated 135 samples. The main content of the survey includes information about the respondents; assessing the influence rates of factors on the mortgage; problems and their causes in making mortgage.

\section{Methods of Processing And Analyzing Data}

Data collected from the land use right mortgage survey were processed and analyzed by using SPSS 20.0 software. The reliability of the scale is verified by Cronbach's alpha coefficient. The data ensure reliability when Cronbach's Alpha coefficient is in the range [0.6 - 0.95] (Hair et al., 1998), the correlation coefficient of the total $>0.3$ (Hair et al., 1998). Discovery factor analysis (EFA) is used to shorten many measurement variables into a set of variables (factors) to make them more meaningful but still contain most of the information of the original set of variables (Hair et al., 1998). EFA was assessed through KMO appropriate coefficient, Bartlett test, Eigenvalues coefficient, total explanatory variance and load factor. Variables are only accepted when the KMO is within the range [0.5 - 1] and its own weight factors in other factors are less than 0.35 (Igbaria et al., 1995) or the distance 
between two load weights (Factor Loading), the same variable in 2 different factors is greater than 0.3. According to Hair et al. (1998), with a sample size of about 100, the weight of the load should be chosen that is greater than 0.55 , so for the sample size 105 , in this study, the chosen load weight is greater than 0.55 . Besides, the scale is only accepted when the total variance explained (Total Variance Explained) is greater than 50\%; Barlett's coefficients with sig significance level are less than 0.05 to ensure the factors are correlated with each other; Eigenvalue coefficients are valued from 1 to ensure the groups of factors have differences. At the same time, the study uses a multivariate linear regression model to determine the influence of factors on land use right mortgages in Yen My district, Hung Yen province. The model has the following form:

$\mathrm{Y}=\beta 1 * \mathrm{CF}+\beta 2 * \mathrm{RF}+\beta 3 * \mathrm{LF}+\beta 4 * \mathrm{HF}+\beta 5 * \mathrm{FF}+\beta 6 * \mathrm{OF}+\beta 7 * \mathrm{DF}+\beta \mathrm{o}$

Where: Y - dependent variable showing the influence of land use right mortgage; $\beta 1 ; \beta 2$; $\beta 3 ; \beta 4 ; \beta 5 ; \beta 6 ; \beta 7$ - regression coefficients of the corresponding variables, respectively mortgage registration, legal factors on land use right mortgage $s$, human factors, facilities factors, financial obligation factors, factors of dealing with land use right mortgage; $\beta \mathrm{o}$ - constant; CF, RF, LF, HF, FF, $\mathrm{OF}, \mathrm{DF}$ - independent variables, respectively mortgage registration, legal factors on land use right mortgage s, human factors, facilities factors, financial obligation factors, factors of dealing with land use right mortgage.

\section{RESULTS AND DISCUSSION}

\section{Overview of Research Area}

Yen My District is located $33 \mathrm{~km}$ from Hanoi, its population of 160,000 people and its natural area of $92.41 \mathrm{~km}^{2}$. The district's economic structure has been shifted towards increasing the proportion of industry - handicrafts and trade - services, sharply reducing the proportion of agriculture (agriculture accounting for $3.22 \%$; industry and construction accounting for rate of $83.25 \%$; trade and services accounted for $13.53 \%$ ). In the recent years, with practical policies and right investment strategy, Yen My has become an attractive destination for domestic and foreign investors (Yen My District People's Committee, 2020).

\section{Result of Iberia Land Use Right Mortgage Registration}

During the research period (2015-2019), the number of applications for land use right mortgage in Yen My district tended to increase (Figure 3).

The largest number of mortgage registration applications in 2019 (2540 cases), greater than the total number of cases (2034 cases) of 2016 (Table 3) because in 2019, many households and individuals who want to borrow money to expand production and business, especially to build houses for rent, but also for consumption, training, career change, labor export... The loan duration of households and individuals is mainly from 1 to 3 years, a few borrow over 3 to 5 years.

In the 2015-2019 period, the total number of mortgage removal cases also tended to increase, but not significantly increased from 280 to 1368 cases in 2 (Table 4). In 2019, the number of mortgage removal increased sharply because many households are due to pay off their bank debts under the contract this year and some other households pay debt early due to land compensation money.

In the 2015-2019 period, there were 102 cases of undue mortgage produced by the borrowers who didn't use ineffectively loan or were destroyed so that they didn't not have money to pay their debts on time. In the period of 2015 - 2019, there were 924 cases of changing mortgage registration content (accounting for $17.54 \%$ of the total number of mortgage registration cases) (Table 5). These cases occurred mainly in Minh Chau commune and Yen My town because in 2019, the real estate 
Figure 2. Location Map of Yen My district, Hung Yen Province

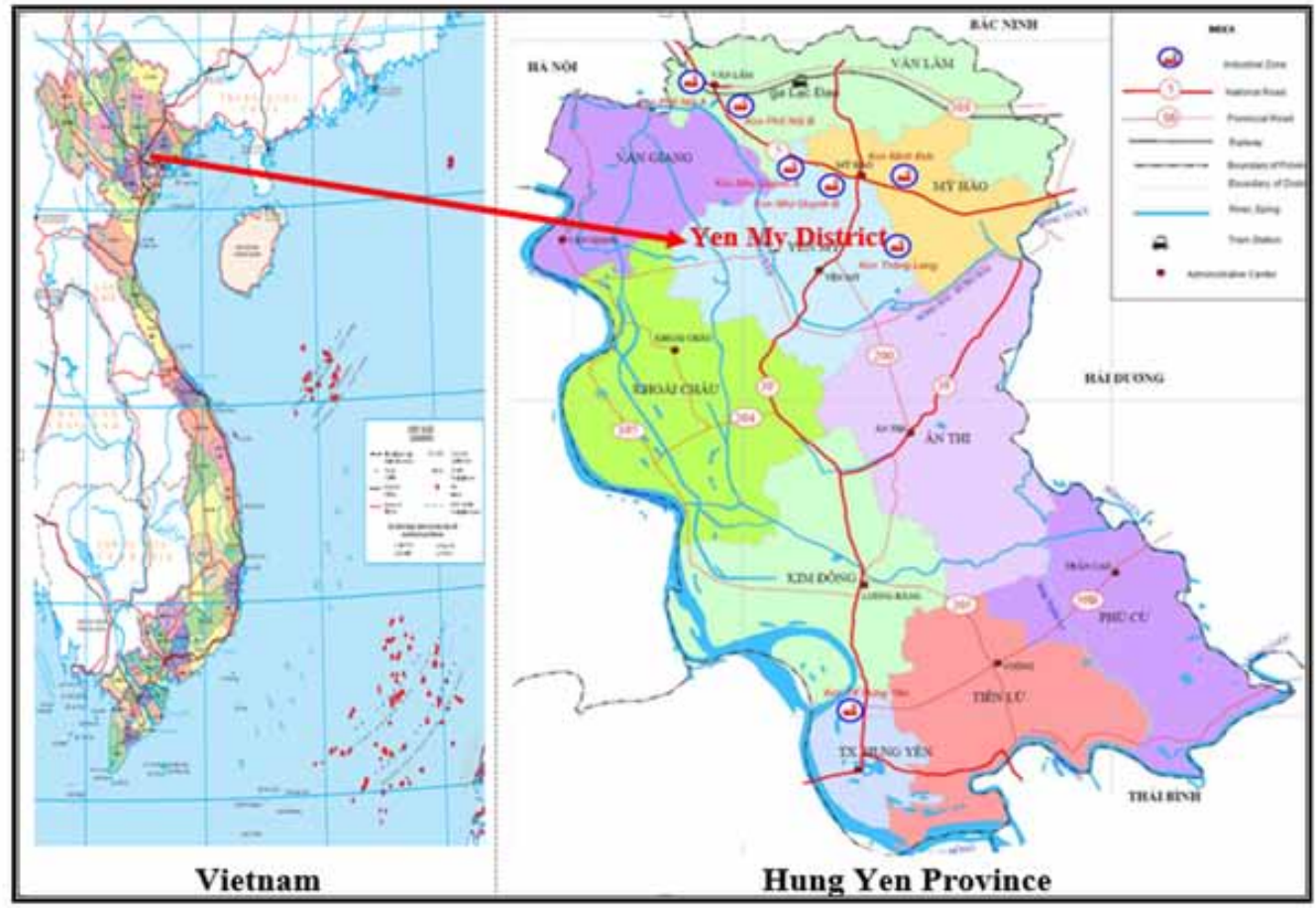

Figure 3. Residential land use right mortgage in Yen My district

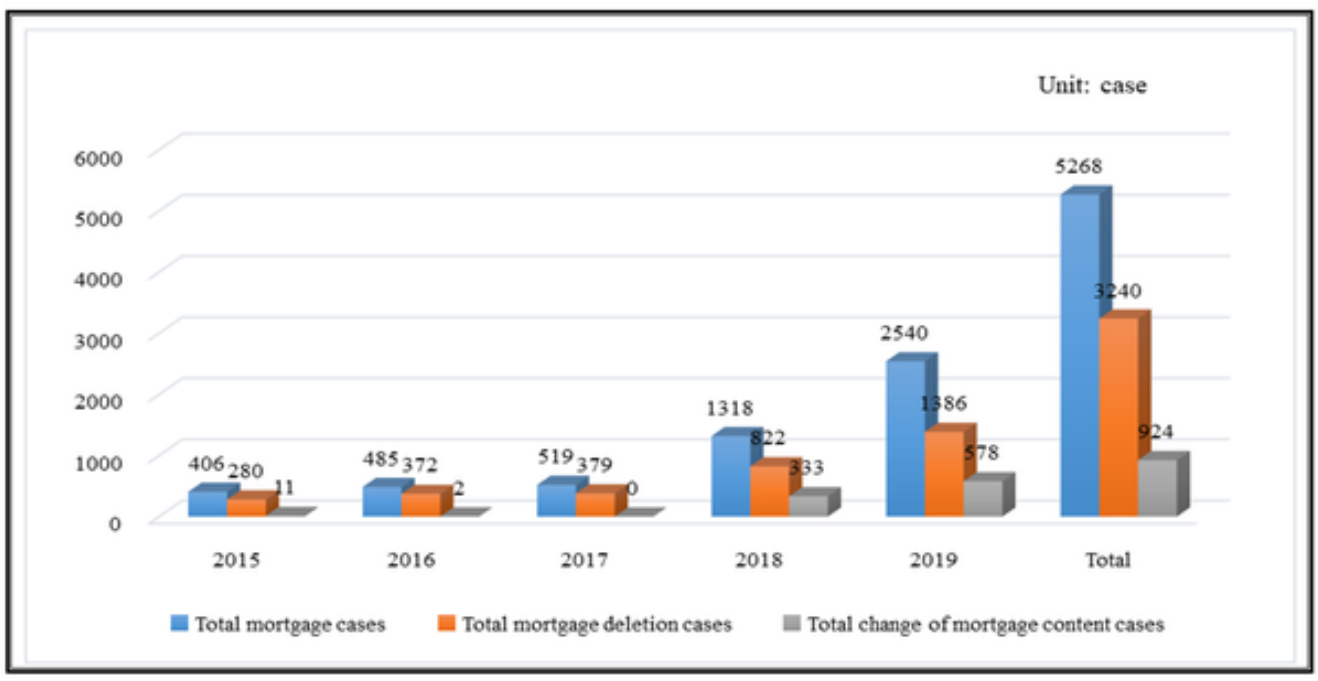


Table 3. Number of land use right mortgage registration dossiers in Yen My district

\begin{tabular}{|l|l|l|l|l|l|l|}
\hline \multicolumn{7}{|c|}{ (Unit: case) } \\
\hline Name of commune & \multicolumn{1}{|c|}{$\mathbf{2 0 1 5}$} & \multicolumn{2}{|c|}{$\mathbf{2 0 1 6}$} & \multicolumn{2}{c|}{$\mathbf{2 0 1 7}$} & \multicolumn{2}{c|}{$\mathbf{2 0 1 8}$} & \multicolumn{2}{c|}{$\mathbf{2 0 1 9}$} & \multicolumn{1}{c|}{ Total } \\
\hline Yen My & 108 & 120 & 118 & 317 & 910 & 1573 \\
\hline rung Ha & 8 & 9 & 8 & 30 & 64 & 119 \\
\hline Trung Hung & 24 & 32 & 30 & 78 & 157 & 320 \\
\hline Ly Thuog Kiet & 8 & 12 & 16 & 48 & 76 & 160 \\
\hline Yen Phu & 19 & 32 & 43 & 75 & 127 & 295 \\
\hline Tan Vie & 23 & 31 & 25 & 81 & 119 & 279 \\
\hline Yen Hoa & 15 & 13 & 11 & 34 & 63 & 135 \\
\hline Minh Chau & 28 & 32 & 26 & 80 & 161 & 327 \\
\hline Thanh Lng & 18 & 17 & 22 & 52 & 120 & 228 \\
\hline Nghia Hep & 17 & 19 & 12 & 64 & 81 & 193 \\
\hline Ngoc Long & 5 & 6 & 13 & 29 & 45 & 98 \\
\hline Tan Lap & 13 & 20 & 29 & 88 & 182 & 332 \\
\hline Lieu Xa & 32 & 26 & 30 & 57 & 78 & 223 \\
\hline Hoan Long & 27 & 31 & 36 & 69 & 86 & 249 \\
\hline Viet Cuong & 3 & 1 & 7 & 12 & 13 & 36 \\
\hline Giai Pham & 33 & 38 & 51 & 107 & 136 & 365 \\
\hline Dong Thn & 27 & 46 & 42 & 97 & 124 & 336 \\
\hline Total & 406 & 485 & 519 & 1318 & 540 & 5268 \\
\hline
\end{tabular}

Source: Branch of Yen My District Land Registration Office (2020)

market was quite vibrant, people mortgaged loans from banks to build more houses and eventually added assets to the certificate to borrow bigger sums from credit institutions.

\section{Evaluation of Factors Influencing Land Use Right Mortgage}

The results of assessing the reliability of the scale through Cronbach's Alpha coefficient for 7 groups of factors show that, Cronbach's Alpha coefficient ranges from $0.814-0.897$, the correlation coefficient of the total variable is greater than 0.3 (Table 6). Thus, the scale used for evaluating the factors affecting the winning price is reliable and suitable for subsequent analysis.

EFA's suitability test is performed through KMO appropriate coefficient. The study results have identified $\mathrm{KMO}=0.893$ and satisfy the condition of $0.5<\mathrm{KMO}<1$, so analyzing the discovery factor is appropriate with actual data. Besides, Barlett test result gives Sig value. equal to 0.00 and less than 0.05 (Table 7). This proves that the measurement variables are linearly correlated with the representative factor. The load factor of components is greater than 0.60 (Table 7), so EFA analysis has practical significance, the independent variables ensure the accuracy included in the regression analysis model to determine the extent the influence of factors on land use right mortgage in the study area.

The results of multivariate regression analysis in Table 9 show that Sig coefficient. equals 0.00 less than the significance level $\alpha$ by $1 \%$ so the regression model is significant, the independent variables influence the dependent variable $\mathrm{Y}$. The adjusted $\mathrm{R}^{2}$ value equal to 0.873 shows that the independent variables are included. Regression run affects $87.3 \%$ of the change of the dependent 
Table 4. Number of cases of land use right mortgage removal in Yen My district

\begin{tabular}{|c|c|c|c|c|c|c|}
\hline \multicolumn{7}{|c|}{ (Unit: case) } \\
\hline $\begin{array}{l}\text { Name of } \\
\text { commune }\end{array}$ & 2015 & 2016 & 2017 & 2018 & 2019 & Total \\
\hline Yen My & 96 & 126 & 124 & 256 & 543 & 1144 \\
\hline Trug Hoa & 6 & 8 & 3 & 11 & 14 & 42 \\
\hline Tung ung & 18 & 27 & 29 & 42 & 81 & 197 \\
\hline Ly Thong iet & 7 & 10 & 10 & 26 & 3 & 85 \\
\hline Yen $\mathrm{Ph}$ & 11 & 19 & 25 & 55 & 68 & 178 \\
\hline Tan Vet & 15 & 20 & 20 & 32 & 39 & 126 \\
\hline Yen $\mathrm{Ha}$ & 8 & 9 & 3 & 6 & 9 & 35 \\
\hline Min Chu & 30 & 34 & 21 & 59 & 99 & 243 \\
\hline ThanhLong & 13 & 13 & 17 & 38 & 87 & 168 \\
\hline NghiaHiep & 13 & 17 & 10 & 25 & 32 & 97 \\
\hline Ngoc Lng & 2 & 2 & 10 & 13 & 20 & 4 \\
\hline Tan La & 8 & 12 & 21 & 64 & 12 & 237 \\
\hline LieuXa & 10 & 10 & 6 & 25 & 34 & 85 \\
\hline Han Lng & 12 & 16 & 20 & 33 & 41 & 122 \\
\hline Viet uong & 1 & 1 & 2 & 5 & 5 & 13 \\
\hline Gia Phm & 18 & 21 & 33 & 59 & 57 & 189 \\
\hline Dong han & 13 & 27 & 25 & 73 & 93 & 231 \\
\hline Total & 28 & 372 & 379 & 822 & 1386 & 324 \\
\hline
\end{tabular}

Source: Branch of Yen My District Land Registration Office (2020)

variable (mortgage by land), the remaining $12.7 \%$ is due to non-model variables and random errors. In addition, the Durbin Watson coefficient has a value of 2,079, ranging from 1.5 to 2.5, so no firstorder sequence correlation occurs. The magnification of the variance (VIF) of all variables included in the model is less than 2, so the research model does not have multi-collinear phenomena. In addition, the variables included in the study are statistically significant (Sig, equal to 0 and less than 0.05). From the standardized regression coefficient, the regression equation has been determined as follows:

$$
\begin{aligned}
& \mathrm{Y}=0.862 * \mathrm{CF}+0.548 * \mathrm{RF}+0.814 * \mathrm{LF}+0.673 * \mathrm{HF}+0.528 * \mathrm{FF}+0.523 * \mathrm{OF}+0.785 * \\
& \mathrm{DF}-4,436
\end{aligned}
$$

The influence of these groups of factors on land use right mortgage in Yen My district, Hung Yen province is shown in Table 9.

The results in Table 9 show that the factor groups included in the research model all affect the land use right mortgage with different influence rates. The credit factor group has the biggest impact on land use right mortgage at the rate of $18.21 \%$. Specifically, in this group of factors, the factors determining the value of land use rights to decide the total loan amount is the most difficult because of the lack of information on market land prices and depends heavily on personal experience of the credit officer. Therefore, in some cases, the value of land use rights of the mortgaged land is not accepted by the borrower. Besides, loan application processing time is also long, affecting the efficiency of loan use. The legal factor group has an impact rate of $17.20 \%$ on the mortgage and the main factor is 
Table 5. Number of cases for changing contents of land registration in Yen My district

\begin{tabular}{|l|l|l|l|l|l|l|}
\hline \multicolumn{9}{|c|}{ (Unit: case) } \\
$\begin{array}{c}\text { Name of } \\
\text { commune }\end{array}$ & $\mathbf{2 0 1 5}$ & $\mathbf{2 0 1 6}$ & $\mathbf{2 0 1 7}$ & \multicolumn{2}{|c|}{$\mathbf{2 0 1 8}$} & \multicolumn{2}{|c|}{$\mathbf{2 0 1 9}$} & \multicolumn{2}{c|}{ Total } \\
\hline Yen My & 2 & 1 & 0 & 74 & 157 & 24 \\
\hline Trun Hoa & 0 & 0 & 0 & 6 & 7 & 13 \\
\hline Trug Hng & 1 & 0 & 0 & 55 & 106 & 12 \\
\hline Ly Tuong iet & 0 & 0 & 0 & 12 & 15 & 27 \\
\hline Yn Ph & 3 & 0 & 0 & 0 & 0 & 3 \\
\hline Tan iet & 0 & 0 & 0 & 28 & 34 & 62 \\
\hline Yn Ho & 0 & 0 & 0 & 7 & 10 & 17 \\
\hline Mih Cau & 2 & 0 & 0 & 72 & 120 & 14 \\
\hline Than Long & 0 & 0 & 0 & 14 & 32 & 46 \\
\hline Nhia iep & 0 & 0 & 0 & 0 & 0 & 0 \\
\hline NgocLon & 1 & 0 & 0 & 6 & 9 & 16 \\
\hline TanLap & 0 & 0 & 0 & 18 & 37 & 55 \\
\hline Leu X & 0 & 0 & 0 & 23 & 31 & 54 \\
\hline Han Lng & 1 & 0 & 0 & 0 & 0 & 1 \\
\hline VietCưg & 0 & 0 & 0 & 0 & 0 & 0 \\
\hline GiaiPha & 1 & 1 & 0 & 17 & 16 & 35 \\
\hline Dng Tan & 0 & 0 & 0 & 1 & 1 & 2 \\
\hline Tota & 11 & 2 & 0 & 333 & 57 & 924 \\
\hline
\end{tabular}

Source: Branch of Yen My District Land Registration Office (2020)

that the legal understanding of many mortgage loans is still limited, leading to slow implementation of mortgage procedures. The group of factors in handling collateral also affects the mortgage of land use rights with an impact rate of $16.59 \%$ due to overlapping and inadequate mortgage handling procedures. The human resource factor and the mortgage registration factor group had the impact rate of $14.22 \%$ and $11.58 \%$. The facilities factor group has the rate of $11.16 \%$. The financial obligation factor group has the smallest effect with rate of $11.05 \%$ (Figure 4) because mortgage registration fees are currently low and acceptable to borrowers when applying for mortgages.

\section{Solutions to Complete Land Use Right Mortgage}

In order to the land use right mortgage to be more completed, it is necessary to carry out a number of solutions according to the priority order based on the mortgage effect of the factors indicated in Table 9.

\section{Completing Procedures For Reviewing Mortgage Loan Documents}

According to the assessment of the land use right mortgage borrowers, the time to review the application file for loan is still long due to the difficulty in determining the value of the mortgaged land due to the lack of information on market land prices. This leads to the value of land determined by the mortgage recipients not accepted by borrowers so the re-valuation is time consuming. Therefore, when valuing mortgaged land, the parties should agree to hire an exclusive land valuation organization to valuate mortgage land. Besides, loan interest rate, loan term, disbursement time after signing the 
Table 6. Results of reliability analysis of the scale

\begin{tabular}{|c|c|c|}
\hline Symbol & Factors and measurement variables & Correlated total variable \\
\hline & 1. Credit Group $(C F-$ Alpha $=0.842)$ & \\
\hline CF1 & - Determining th value of mortgaged land & 0.723 \\
\hline $\mathrm{CF} 2$ & - Loan amont & 0.651 \\
\hline $\mathrm{CF} 3$ & - Loan ters & 0.726 \\
\hline CF4 & - Loan intrest ate & 0.694 \\
\hline \multirow[t]{2}{*}{ CF5 } & - Time fordocumnt evaluation and disbursement & 0.762 \\
\hline & 2. Mortgage Reitration Factor Group $(R F-$ Alpha $=0.851)$ & \\
\hline RF1 & - Publicizing th content of mortgage registration documents & 0.634 \\
\hline RF2 & $\begin{array}{l}\text { - Form of eceivng mortgage documents (in person or by } \\
\text { mail) }\end{array}$ & 0.723 \\
\hline RF3 & - Time to roces cases & 0.682 \\
\hline \multirow[t]{2}{*}{ RF4 } & - Handlingcomplints & 0.759 \\
\hline & 3. Legal FactosGroup $(L F-$ Alpha $=0.882)$ & \\
\hline LF1 & - Regulations onland use right mortgage & 0.765 \\
\hline LF2 & - Disseminting egulations on land use right mortgage & 0.797 \\
\hline LF3 & - Knowing he motgage mortgage's regulations on mortgage & 0.659 \\
\hline \multirow[t]{2}{*}{ LF4 } & $\begin{array}{l}\text { - Sense ofcomplance with regulations on land use right } \\
\text { mortgage of mortgagors }\end{array}$ & 0.754 \\
\hline & 4. Human Facto roup of HF - Alpha $=0.897$ ) & \\
\hline HF1 & - Qualification & 0.683 \\
\hline HF2 & - Communiction kills & 0.734 \\
\hline HF3 & - Ability o coodinate to solve the work & 0.769 \\
\hline \multirow[t]{2}{*}{ HF4 } & - Ability o sole situations & 0.635 \\
\hline & 5. Facilities ator Group $(M F-$ Alpha $=0.814)$ & \\
\hline FF1 & - Cadastral dataase & 0.775 \\
\hline $\mathrm{FF} 2$ & - Cadastra datastorage device & 0.742 \\
\hline \multirow[t]{2}{*}{ FF3 } & - Place ofreceiing and processing cases & 0.683 \\
\hline & 6. Financial Olgation Factor Group $(O F-$ Alpha $=0.863)$ & \\
\hline OF1 & - Loan applicatin evaluation fee & 0.734 \\
\hline OF2 & - Notary fe of ortgage contract & 0.750 \\
\hline \multirow[t]{2}{*}{ OF3 } & - Mortgageregisration fee & 0.692 \\
\hline & 7. Handling colteral Factor Group (DF - Alpha $=0.827)$ & \\
\hline DF1 & - Mortgage handlng form & 0.778 \\
\hline DF2 & - Civil prcedur & 0.736 \\
\hline DF3 & - Collaterl aucion & 0.747 \\
\hline DF4 & - Judgmentexecuion & 0.724 \\
\hline
\end{tabular}


International Journal of Service Science, Management, Engineering, and Technology

Volume $13 \cdot$ Issue 1

Table 7. KMO and Bartlett's test reults

\begin{tabular}{|l|l|l|}
\hline \multicolumn{2}{|c|}{ Kaiser-Meyer-Olkin Measure of Sampling Adequacy } & \multicolumn{1}{c|}{$\mathbf{0 . 8 9 3}$} \\
\hline \multirow{3}{*}{ Bartlett's Test of Sphericity } & Approx. Chi-Square & 1861,642 \\
\cline { 2 - 3 } & df & 172 \\
\cline { 2 - 3 } & Sig. & 0.000 \\
\hline
\end{tabular}

Table 8. Weights of rotation matrix

\begin{tabular}{|c|c|c|c|c|c|c|c|}
\hline \multirow{2}{*}{$\begin{array}{c}\text { Variable } \\
\text { measurement }\end{array}$} & \multicolumn{7}{|c|}{ Group of influencing factors } \\
\hline & 1 & 2 & 3 & 4 & 5 & 6 & 7 \\
\hline DF & 0.76 & & & & & & \\
\hline DF2 & 0.753 & & & & & & \\
\hline DF1 & 0.742 & & & & & & \\
\hline DF3 & 0.734 & & & & & & \\
\hline $\mathrm{CF} 1$ & & 0.876 & & & & & \\
\hline CF3 & & 0.824 & & & & & \\
\hline $\mathrm{CF} 2$ & & 0.783 & & & & & \\
\hline CF5 & & 0.775 & & & & & \\
\hline $\mathrm{CF} 4$ & & 0.766 & & & & & \\
\hline $\mathrm{HF} 2$ & & & 0.753 & & & & \\
\hline HF4 & & & 0.741 & & & & \\
\hline HF3 & & & 0.695 & & & & \\
\hline HF1 & & & 0.687 & & & & \\
\hline $\mathrm{OF} 2$ & & & & 0.875 & & & \\
\hline $\mathrm{OF} 3$ & & & & 0.861 & & & \\
\hline OF1 & & & & 0.853 & & & \\
\hline RF3 & & & & & 0.869 & & \\
\hline RF2 & & & & & 0.842 & & \\
\hline $\mathrm{RF} 1$ & & & & & 0.835 & & \\
\hline RF4 & & & & & 0.821 & & \\
\hline LF3 & & & & & & 0.773 & \\
\hline LF1 & & & & & & 0.745 & \\
\hline LF2 & & & & & & 0.712 & \\
\hline LF4 & & & & & & 0.693 & \\
\hline FF1 & & & & & & & 0.854 \\
\hline FF3 & & & & & & & 0.821 \\
\hline FF2 & & & & & & & 0.808 \\
\hline
\end{tabular}


Table 9. Results of linear regression analysis

\begin{tabular}{|c|c|c|c|c|c|c|}
\hline \multirow{2}{*}{$\begin{array}{l}\text { Group of } \\
\text { factors }\end{array}$} & \multirow{2}{*}{$\begin{array}{l}\text { Regression } \\
\text { coefficients }\end{array}$} & \multirow{2}{*}{$\mathbf{t}$} & \multicolumn{2}{|c|}{ Multicollinear satistics } & \multirow{2}{*}{$\begin{array}{c}\text { Impact rate } \\
(\%)\end{array}$} & \multirow{2}{*}{$\begin{array}{l}\text { Order of } \\
\text { influene }\end{array}$} \\
\hline & & & Error (Sig.) & VIF & & \\
\hline Constant & -4.43 & & & & & \\
\hline $\mathrm{CF}$ & 0.862 & 4.548 & 0 & 1.739 & 18.21 & 1 \\
\hline $\mathrm{LF}$ & 0.814 & 5.52 & 0 & 1.731 & 17.20 & 2 \\
\hline DF & 0.785 & 4.61 & 0 & 1.648 & 16.59 & 3 \\
\hline $\mathrm{HF}$ & 0.673 & 5.03 & 0 & 1.743 & 14.22 & 4 \\
\hline $\mathrm{RF}$ & 0.548 & 4.33 & 0 & 1.425 & 11.58 & 5 \\
\hline $\mathrm{FF}$ & 0.528 & 6.81 & 0 & 1.844 & 11.16 & 6 \\
\hline OF & 0.523 & 5.41 & 0 & 1.553 & 11.05 & 7 \\
\hline
\end{tabular}

Figure 4. Influence levels of factor groups on land use right mortgage in Yen My district

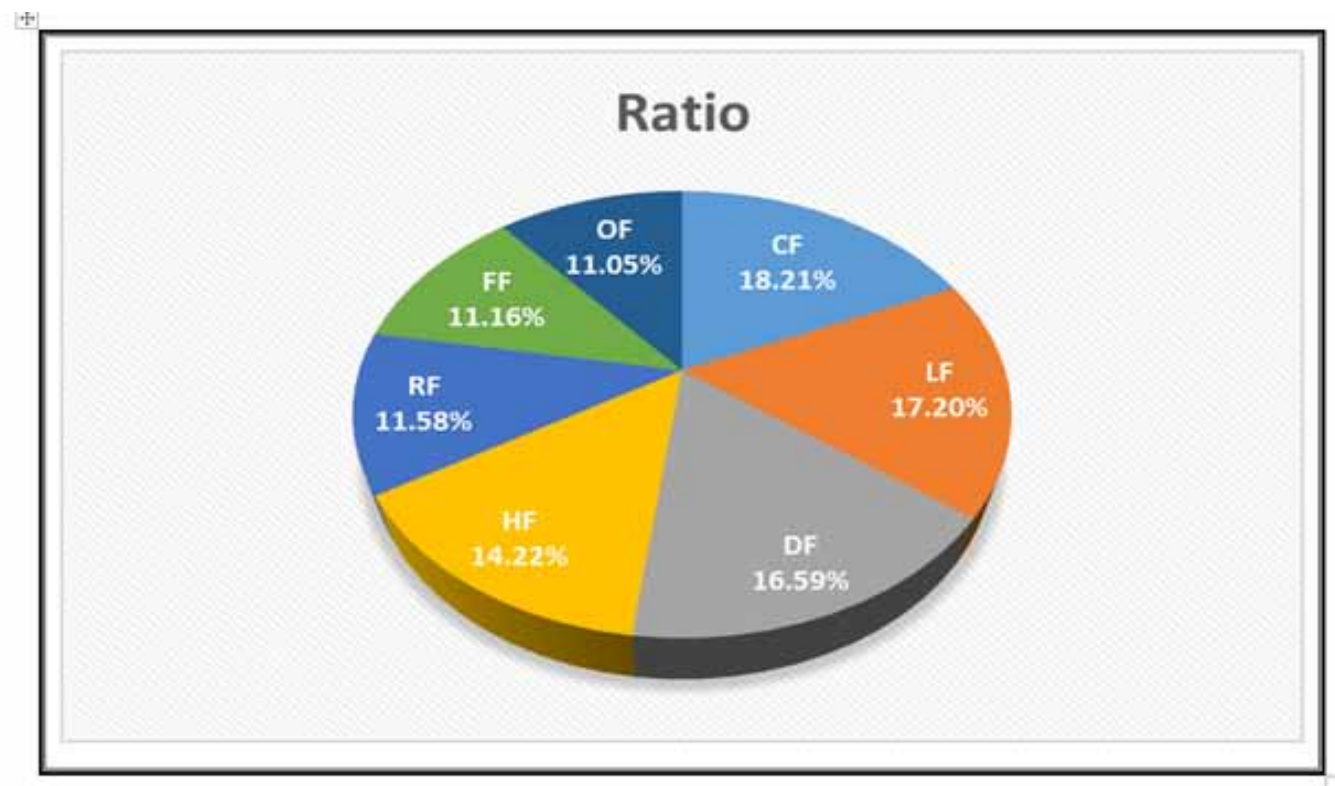

mortgage contract are also issues that the borrower is not satisfied in many cases. In order to solve this inadequacy, lenders need to publicize loan interest rates, loan terms, disbursement time and strictly abide by such regulations and commit to compensate customers if they do not comply with regulations. Currently, although the law allows land users to be allowed to mortgage with their land in many organizations but this right has not been exercised because the land certificate held by the lender. Therefore, to ensure the rights of land users, it is necessary to return the land certificate to the borrower but disclose the legal status of the land plot so that the lender will know the land plot as a basis for decision whether to lend or not to lend. 


\section{Amending and Adding Regulations On Mortgage Lending}

According to Point, Clause 1, Article 179 of the 2013 Land Law, households and individuals using land may mortgage lands at credit institutions licensed to operate in or business organizations. However, there are no specific regulations on notarization or certification of contracts when land users mortgage their land at non-credit institutions, so they do not be notarized or certified by the local mortgage contract is still disturbed, concerned that the registration of this mortgage may lead to the legalization of "black credit" (a form of usury); at risk of mortgaging the mortgage party (currently lending legally belongs to banks and finance companies registered under the law regulated by the 2010 Law on Credit Institutions and according to the regulation, Lending interest rates of credit institutions must be within the permitted limits). Therefore, to ensure the creation of favorable conditions for the people to exercise their rights in accordance with the law, at the same time, to avoid possible risks, according to the assigned functions and tasks, to propose ministries, relevant agencies review and finalize specific guidelines according to their competence or advise the Government to promulgate regulations to clarify the responsibilities of the parties in case individuals mortgage their land and assets attached to land at economic organizations or individuals other than credit institutions.

\section{Completing Procedures To Handle Mortgage Debt}

During the research period in Yen My district, there were 17 cases which were unable to pay debts on time, so they were sued to the Court for settlement by the recipient. The mortgage borrower and the mortgage lender do not agree on a plan to transfer or auction the land to recover the loan and interest. The Court's decision usually takes a lot of time, effort of the parties because they have to be present under the summons of the Court and the procedure is also very complicated. To overcome this limitation in the mortgage contract, the parties need to agree on the form of handling land when the borrower loses the ability to perform financial obligations such as the transfer of land, or auction sale, or sue the Court or under the judgment of the Economic Arbitration (the judgment of the Economic Arbitration should be applied because it is faster to settle the lawsuit form). At the same time, it is necessary to research and assign a specialized agency with the functions of all three organizations (the Court, the Judicial Execution Agency and the auction organization) to carry out the task of simultaneous trial work, execution of judgments, auction when handling collateral. The agency in charge of issuing the decision to open the land auction procedure and the distraint declaration for the land are collaterals to be handled after having verified the papers in the borrower's handling request dossier. The coercive seizure will be performed by the Competent Authority. In case of necessity, this Agency may request assistance from the Police Department and local authorities.

\section{Completing Human Resources, Facilities And Mortgage Registration Procedures}

According to the survey results, people who register for mortgage using land still have some mortgage receivers who have not provided specific instructions and details of mortgage procedures; checking cases is not thorough, so when dealing with new cases, errors should be requested by mortgagors to make additional adjustments, causing loss of time and frustration for people. In order to limit this phenomenon, it is necessary to recruit recipients to master the mortgage rules and be able to guide people to prepare documents that are easy to understand and comply with regulations. Besides, in order to receive mortgage registration documents of land quickly, to avoid the need for people to wait for a long time, it is necessary to have a registration system that allows people to register by phone or via internet network then they will visit the Branch Office of Land Registration with the notice of time to receive cases exactly to each hour and every minute so that they can take the initiative in time. To achieve this requirement, it is necessary to build a multi-purpose land information system. 


\section{Freeing Loan Dossier Evaluation}

Currently, many credit institutions charge a fee for evaluating a mortgage loan by a land user with a fee of 500,000 - 1,000,000 VND (23,000VND = 1USD)/profile based on the location of the mortgaged land plot and the expected loan amount of borrowers. This amount is set by credit institutions, so it is often not accepted by borrowers because they think that the appraisal of loan documents is the obligation of credit institutions when borrowers have submitted all required documents as prescribed. Therefore, the lender should consider waiving this due diligence fee to avoid causing a nuisance to the borrowers.

\section{CONCLUSION}

In the period of 2015-2019, in Yen My district, Hung Yen province, there were 5268 mortgage registration documents, 3240 cases of land use right mortgage removal, 102 cases of undue mortgage, 924 cases changing content of mortgage registration. The research results showed that the factors included in the research model all affect the land use right mortgage with different influence rates. The credit factor group has the biggest impact on land use right mortgage at the rate of $18.21 \%$, followed by the legal factor group on land use right mortgage at the rate of $17.20 \%$, dealing factor group with the rate of $16.59 \%$, human factor group with the rate of $14.22 \%$, mortgage registration factor group with the rate of $11.58 \%$, facilities factor group with the rate of $11.16 \%$ and the smallest effect is financial obligation factor group with rate of at $11.05 \%$. In order to improve the efficiency of land use right mortgage, it is necessary to be more completed procedures for reviewing mortgage loan documents; amending and adding regulations on mortgage lending; completing procedures to handle mortgage debt; completeing human resources, facilities and mortgage registration procedures; freeing loan dossier evaluation.

\section{ACKNOWLEDGMENT}

The author would like to thank the People's Committee of Yen My District and Master Nguyen Thi Dieu Linh for their help in the data collection process to complete this study. 


\section{REFERENCES}

Aikhuele, D., \& Turan, F. (2018). A Conceptual Model for the Implementation of Lean Product Development. International Journal of Service Science, Management, Engineering, and Technology, 9(1), 1-9. doi:10.4018/ IJSSMET.2018010101

Akhter, J., Tandon, D., \& Kulshreshtha, G. (2021). The Effectiveness of Credit-to-GDP Gap as a Leading Indicator of Banking Crises in India. International Journal of Service Science, Management, Engineering, and Technology, 12(1), 17-37. doi:10.4018/JJSSMET.2021010102

Ambrose, B. W., Conklin, J. N., \& Lopez, L. A. (2020). Does Borrower and Broker Race Affect the Cost of Mortgage Credit? Academic Press.

Anderson, K. M., \& Kurzer, P. (2020). The politics of mortgage credit expansion in the small coordinated market economies. West European Politics, 43(2), 366-389. doi:10.1080/01402382.2019.1596421

Anenberg, E., Hizmo, A., Kung, E., \& Molloy, R. (2019). Measuring mortgage credit availability: A frontier estimation approach. Journal of Applied Econometrics, 34(6), 865-882. doi:10.1002/jae.2720

Anjum, A., Ming, X., \& Puig, L. C. M. (2019). Analysis of Strategic Human Resource Management Practices in Small and Medium Enterprises of South Asia. International Journal of Service Science, Management, Engineering, and Technology, 10(1), 44-61. doi:10.4018/IJSSMET.2019010104

Anna, P. (2020). Legal aspects of synchronising data on real property location in polish cadastre and land and mortgage register. Land Use Policy, 95, 104606. doi:10.1016/j.landusepol.2020.104606

Basharat, T. (2020). Applying ISPAR Model of Service Dominant Logic on Mentoring a Part of Training and Development Function of HRM Functions. International Journal of Service Science, Management, Engineering, and Technology, 11(1), 46-54. doi:10.4018/IJSSMET.2020010104

Bello, T. (2017). Mortgage Matrix and Bank Lending; An Evaluation of Mortgage Consent. An Evaluation of Mortgage Consent.

Blackburn, M., \& Vermilyea, T. (2007). The role of information externalities and scale economies in home mortgage lending decisions. Journal of Urban Economics, 61(1), 71-85. doi:10.1016/j.jue.2006.05.005

Bogin, A. N., \& Shui, J. (2020). Appraisal Accuracy and Automated Valuation Models in Rural Areas. The Journal of Real Estate Finance and Economics, 60(1), 40-52. doi:10.1007/s11146-019-09712-0

Branch of Yen My Land Registration Office. (2020). Report on the results of land mortgage registration. Author.

Briggs, C., \& Zuijderduijn, J. (2018). Land and Credit: Mortgages in the Medieval and Early Modern European Countryside. Springer. doi:10.1007/978-3-319-66209-1

Burns, R. (2017). A Foreclosure on Consumer Rights: Pennsylvania's Denial of Counterclaims in Mortgage Foreclosure Actions under the Truth in Lending Act. Temp. L. Rev., 90, 347.

Chauvet, M., Gabriel, S., \& Lutz, C. (2016). Mortgage default risk: New evidence from internet search queries. Journal of Urban Economics, 96, 91-111. doi:10.1016/j.jue.2016.08.004

Cho, M., \& Megbolugbe, I. F. (1996). An empirical analysis of property appraisal and mortgage redlining. The Journal of Real Estate Finance and Economics, 13(1), 45-55. doi:10.1007/BF00174550

Do, Q., \& Iyer, L. (2008). Land Titling and Rural Transition in Vietnam. Economic Development and Cultural Change, 56(3), 531-579. doi:10.1086/533549

Ertl, C., Herzfeldt, A., Floerecke, S., \& Krcmar, H. (2020). Ensuring the Success of Management Accounting Change in IT Departments of Public Organizations. International Journal of Service Science, Management, Engineering, and Technology, 11(1), 142-156. doi:10.4018/ISSSMET.2020010109

Fisher, L. M. (2006). Renegotiation in the Common Law Mortgage and the Impact of Equitable Redemption. The Journal of Real Estate Finance and Economics, 32(1), 61-82. doi:10.1007/s11146-005-5178-8 
Galli, B. J. (2020). Economic Decision-Making in Private Corporations Versus Public Sector: How to Compare Both Sectors. International Journal of Service Science, Management, Engineering, and Technology, 11(1), 73-98. doi:10.4018/IJSSMET.2020010106

Gallin, J., Molloy, R., Nielsen, E., Smith, P., \& Sommer, K. (2021). Measuring aggregate housing wealth: New insights from machine learning. Journal of Housing Economics, 51, 101734. doi:10.1016/j.jhe.2020.101734

Hair, J. F. Jr, Anderson, R. E., Tatham, R. L., \& Black, W. C. (1998). Multivariate Data Analysis (5th ed.). Macmillan Publishing Company.

Hanewald, K., Bateman, H., Fang, H., \& Wu, S. (2020). Is there a demand for reverse mortgages in China? Evidence from two online surveys. Journal of Economic Behavior \& Organization, 169, 19-37. doi:10.1016/j. jebo.2019.10.023

Hendershott, P. H., \& Pryce, G. (2006). The sensitivity of homeowner leverage to the deductibility of home mortgage interest. Journal of Urban Economics, 60(1), 50-68. doi:10.1016/j.jue.2006.01.003

Lee, H., \& Bostic, R. W. (2020). Bank adaptation to neighborhood change: Mortgage lending and the Community Reinvestment Act. Journal of Urban Economics, 116, 103211. doi:10.1016/j.jue.2019.103211

Levine-Schnur, R. (2020). Measuring the Effectiveness of Real Estate Regulation: Interdisciplinary Perspectives. Springer. doi:10.1007/978-3-030-35622-4

$\mathrm{Li}, \mathrm{K}$. (2017). The mode selection of rural land contract management right mortgage loan in china. In $\mathrm{Z}$. Henan \& J. Y. Beijing (Eds.), 2016 National Convention on Sports Science of China (p. 01003). EDP Sciences. doi: $10.1051 / \mathrm{ncssc} / 201701003$

Li, L., \& Yavas, A. (2017). Land Share, Mortgage Default, and Loan-to-Value Ratio as a Macro-Prudential Policy Tool. Academic Press.

Mączyńska, A., \& Kwartnik-Pruc, A. (2017). Land ownership act as a basis for legal status regulation of real estate located in rural areas. Infrastruktura i Ekologia Terenów Wiejskich.

Martin, H., \& Hanson, A. (2016). Metropolitan area home prices and the mortgage interest deduction: Estimates and simulations from policy change. Regional Science and Urban Economics, 59, 12-23. doi:10.1016/j. regsciurbeco.2016.03.006

Mizuno, Y., \& Odake, N. (2019, April 1). An Empirical Analysis of an Organizational Continuum in a Japanese Accounting Cloud Service. International Journal of Service Science, Management, Engineering, and Technology, 10(2), 1-21. doi:10.4018/IJSSMET.2019040101

Mulolwa, A. (2016). Land Governance Assessment: Zambia Country Report. World Bank. doi:10.1596/28503

Resmawan, I. P. A. P., \& Andjarwati, A. (2018). The Implication of Computerized System-Based Mortgage Right Registration. Jurnal Notariil, 3(2), 97-108.

Salampessy, M. L., Febryano, I. G., \& Zulfiani, D. (2019). Principal agent in tree mortgage system on traditional agroforestry management in Moluccas Indonesia. IOP Conference Series: Earth and Environmental Science, 285(1), 012013. doi:10.1088/1755-1315/285/1/012013

Shi, X. (2016). Mortgage Enforcement and Public Regulatory Actions in China in Selected Chinese Cities. Lincoln Institute of Land Policy.

Steil, J. P., Albright, L., Rugh, J. S., \& Massey, D. S. (2018). The social structure of mortgage discrimination. Housing Studies, 33(5), 759-776. doi:10.1080/02673037.2017.1390076 PMID:30100661

Sulasningsih, S., Warman, K., \& Najmi, N. (2020). Deletion of Mortgage Rights on Certificate of Ownership in the Event That the Mortgage Title Certificate Is Lost in the Kampar Regency. International Journal of Multicultural and Multireligious Understanding, 6(6), 600-608.

Susilowati, S., \& Gunarto, G. (2018). Legal Consequences of Mortgage Right Imposition On Uncertified Land (Letter C) In Case The Grantor Is Passed Away. Jurnal Akta, 5(2), 427-434. doi:10.30659/akta.v5i2.3098

Tzioumis, K. (2017). Mortgage (mis)pricing: The case of co-borrowers. Journal of Urban Economics, 99, 79-93. doi:10.1016/j.jue.2016.12.004 
Wang, Y., Li, X., He, H., Xin, L., \& Tan, M. (2020). How reliable are cultivated land assets as social security for Chinese farmers? Land Use Policy, 90, 104318. doi:10.1016/j.landusepol.2019.104318

Wardhana, D. S., \& Witasari, A. (2018). The Role of The Land Deed Officials in Mortgage Right Credit Agreement in PT. Bank Jateng Branch Slawi, Tegal Regency. Jurnal Akta, 5(3), 597-602. doi:10.30659/akta.v5i3.3159

Yang, X., Luo, J., \& Yan, W. (2018). Heterogeneous effects of rural land property mortgage loan program on income. China Agricultural Economic Review, 10(4), 695-711. doi:10.1108/CAER-12-2015-0179

Ye, C., \& Gao, C. (2019). Construction of Mortgage Risk Index System for Farmland Management Right. 2018 6th International Education, Economics, Social Science, Arts, Sports and Management Engineering Conference (IEESASM 2018).

Yen My District People's Committee. (2020). Report on the situation of socio-economic development in 2019, orientation for 2020 in Yen My district. Author.

Zhang, Y. (2020). Influence Factors of Attitude of Offspring on the Demand for Housing Reverse Mortgage Endowment Insurance in China. Financial Engineering and Risk Management, 3(1), 23-30.

Zhimin, Z., \& Jianchao, L. U. (2017). "Cold Shoulder” Experience of Farmland Property Right Mortgage Based on the questionnaire of 1250 households in Jiangxi Province. Agricultural Science and Technology, 18(5). 